\title{
CITIZENSHIP AND UNSYSTEMATIC ACTION OF INTELLECTUALS IN SOVIET LITHUANIA
}

\author{
Aurimas Šukys
}

ABSTRACT The subject of this article is an assessment of unsystematic action by intellectuals in Soviet Lithuania according to the criterion of citizenship. Unsystematic action is understood as an everyday, institutional and theoretical activity that is at variance with Marxist-Leninist ideology and the Soviet totalitarian state that embodied it in one or another form. Our research is based on the premise that the form of the totalitarian state, which Lithuanian society endured after the Second World War and especially after Stalin's death, changed ever-more considerably with time creating some favourable possibilities for independent social action. Another significant term 'citizenship' is used here in a republican rather than liberal sense underlying the participation of the inhabitants of the state 'from below' in the activity of the society being formed in which it was sought to defend the general public interest, and human rights, as well as the rights of a citizen. On the basis of a theoretical analysis of different authors, a general model of the functioning of civil society existing in Western society is presented here and on this basis the statement is made that there were three manifestations of such citizenship in Soviet Lithuania: anti-systematic, unsystematic and systematic. The practice of unsystematic action, which was initiated by informal groups of the cultural elite, is considered in more detail.

The theme of citizenship in present-day Lithuania (and elsewhere) is a frequent subject of research and discussion. Quite often this phenomenon is considered to be a panacea in modern society. It is often noted that if there had there been no Soviet occupation, Lithuania would have been more democratic, more civil, and hence, much happier. When investigating citizenship within the post-Soviet context, some investigators contrast it with the model of government of the totalitarian state that subjugated other nations. Researchers into the totalitarian tendency base themselves on the supposition that absolutely everything was controlled by the regime in the Soviet Union and society in such a state was too atomised for a sufficient drive to 
free itself from the clutches of control to appear. ${ }^{1}$ Some authors of revisionist tendency turn their attention to the history of resistance: post-war resistance, dissident, underground activity. ${ }^{2}$ In their opinion very clear anti-Soviet attitudes were hidden in the history of such open or uncompromising opposition to the totalitarian regime and the only way to live a normal life was to live freely: to have one's own government, laws, and organisations in a free country. The post-war partisan struggle, the activities of the Lithuanian Freedom League, Helsinki Group, the Chronicle of the Catholic Church of Lithuania and individual dissidents or spontaneous challenges posed openly to the Soviet system through celebrations of All Saints' Day in Kaunas and Vilnius, and the day on which Romas Kalanta immolated himself were a clear expression of a strong public will. However, it is possible to take another step and see whether, apart from open uncompromising resistance, there were any other possible manifestations of citizenship in Soviet Lithuania, which could in their essence not be related to loyalty to the Soviet state and communist ideology, and manifested themselves in a legal or semi-legal space. Among different groups of a society governed by the Soviets, there were many who were able to choose the path of alternative culture, a social activity other than opposition and collaboration. When living under abnormal Soviet conditions it was also possible to choose what was not in direct opposition to the system but a certain social or possibly civil alternative. Finally the Sajūdis movement, which brought political independence to Lithuania, was born from the alternatives, the intellectuals who chose non-systematic social and professional action and the majority of the residents of Lithuania who approved of them rather than from direct open opposition to the regime. Therefore, the aim of this article is to analyse the model of citizenship and manifestations of its non-systematic action in a legal and semi-legal space among Soviet Lithuanian intellectuals.

Non-systematic action means what was not in line with Soviet Marxist ideology and an everyday, institutional and theoretical activity implementing it in the Soviet state. ${ }^{3}$ In this article, this conception

${ }^{1}$ D. Marcinkevičienè, 'Sovietmečio istoriografija: užsienio autorių tyrinejjimai ir interpretacijos' Lietuvos istorijos metraštis, 2003, 2, pp. 91-94.

${ }^{2}$ Ibid, p. 98.

${ }^{3}$ These concepts - non- and anti-systematic - are also used by other Lithuanian Sovietologists, See: A. Ramonaite, 'Pilietinè visuomene Sovietų Lietuvoje?', Naujasis Židinys, 2010, Nos. 7-8, pp. 252-257; A. Streikus, 'Lietuvos katalikų pilietinio aktyvumo pavyzdžiai ir ribos XX amžiuje’, ibid., Nos. 9-10, pp. 316-321. 
is sometimes replaced with the word 'alternative' action, which on its own embraces not only non-systematic, but also anti-systematic actions. Non-systematic may also mean oppositional, though not always, because opposition expresses contraposition of a certain degree, and a non-systematic or alternative action can have no contact with the system, its functioning and may exist simply next to the system. It is new that some ways of non-systematic actions are interpreted as manifestations of citizenship in the Soviet state in this article.

The sources of this research are memoirs, diaries, data collected in interviews with intellectuals, and published KGB documents. Since there is a considerable growth of primary sources about different intellectual actions and initiatives in the late Soviet period (even about the same actions and the same people), analytic comparison of them helped to avoid biased retrospective evaluations or memory simulations by witnesses. ${ }^{4}$

\section{The Western citizenship model and possibilities for it to function} in Soviet Lithuania To identify manifestations of social awareness in Soviet space it is necessary to describe the model of citizenship in some detail. Western political scientists and sociologists when defining citizenship and civil society present in essence two interpretations: one liberal, the other, republican (community-based) . ${ }^{5}$ The first viewpoint places greater emphasis on rights and duties, as well as on a citizen's individuality. In this case, rights and duties are granted to a citizen as a certain legal status in the state and this generally encompasses the conception of citizenship. In the second case, following David Miller, the republican concept of citizenship underlines an individual's role in creating and maintaining various forms of sociality, the society itself and in defending the rights of every member, citizen of society in public. ${ }^{6}$ In the interpretation of citizenship in

${ }^{4}$ For example, there is an obvious overestimation of the efforts to revive paganism using the movement of Ramuva in the interview with J. Trinkūnas. In fact, comparing data from other interviews given by other Ramuva leaders or active members, such as V. Mačiekus, V. Bagdonavičius, A. Patackas and V. Povilionis, one can understand that this movement was far more multiple and people with quite different values could be active participants in this organization, established in 1970 . We can also notice that the data about actions to defend the cultural heritage in the Old Town of Vilnius support each other both in the diary of M. Martinaitis (1977), in the minutes of discussion between the intellectuals and officers in charge (1978) and in the interview with G. Martinaitiene made in 2009.

${ }^{5}$ The Encyclopaedia of Democracy, comp. S.M. Lipset (London, 1995), pp. 217-221.

${ }^{6}$ D. Miller, Citizenship and National Identity (Cambridge-Oxford-Malden, 2002). 
which participation of each individual, the active role of a citizen in solving different political and social problems is underlined, the most important thing is not to be the first to come to vote, not to pay taxes on time or to show one's usual official participation in a legal political sphere in other ways but to organise oneself independently and manage one's future: when a group for preserving a historical monument is formed, when a discussion about preserving family values is held or when a group to solve other problems is formed. ${ }^{7}$ Within this context, citizenship manifests itself in human actions as a virtue, which was advocated and cherished already by the ancient Greeks and Romans and which is implemented as self-discipline, patriotism and sacrifice of private interests for the sake of general good. ${ }^{8}$ Miller also underlines the significance of nationality in the formation of a civil society because in an alienated industrial state nationalism helps create necessary solidarity in society, which cannot be done by family connections or interpersonal communication. ${ }^{9}$ In carrying out detailed empirical research into the civil society of Italy R. D. Putnam based himself on the same republican theoretical approach, thinking that with the flow of citizens of liberal tendency increasing, possibilities for society to successfully function decrease proportionally. ${ }^{10} \mathrm{He}$ distinguishes several very important features of the civil community: 1) civic engagement (the principle of the common good), 2) political equality, 3) interrelations between solidarity, trust and tolerance characteristic of members of the community and 4) voluntary organisations. ${ }^{11}$ In his opinion, when relations of solidarity and trust appear among the people strong associations are created, which, in their turn, accomplish not only the common aspirations of members but also help institutions function more efficiently.

It can be said that action characteristic of a civil society and all manifestations of citizenship is between society and the state and it

${ }^{7}$ D. Mathews, 'Concept of a civil society': Democracy is a Discussion. Civic Engagement in Old and New democracies, comp. S. Myers (New London, 1997), p. 24.

${ }^{8}$ Encyclopaedia of Democracy. Also R.D. Putnam, Kad demokratija veiktu. Pilietinès tradicijos šiuolaikinejje Italijoje (Vilnius, 2001), p. 120.

${ }^{9}$ Miller, Citizenship, p. 32. More authors write about the importance of nationalism to the formation of civil society: J. Keane, Civil Society, Old Images, New Visions (Cambridge-Oxford, 1998) p. 86. Remeikis speaks about institutional nationalism. See: T. Remeikis, Opposition to Soviet rule in Lithuania: 1945-80 (Chicago, 1980).

${ }^{10}$ Putnam, Kad demokratija, p. 120.

${ }^{11}$ Ibid., pp.120-122. 
encompasses sociality, the initiative coming from the citizens themselves, striving for general good ('civil altruism') and publicity. The latter aspect does not necessarily overlap with a political activity but, as has already been mentioned, can cover much lower levels of society organisation. The main issue that is of importance within the context of this research is as follows: is it possible to look for the manifestations of civil society, social awareness in a totalitarian state, Soviet Lithuania? Moreover, if it is possible, what manifestations of citizenship and civil society exist?

Some Lithuanian researchers note the fact that in Soviet Lithuania there were strong rudiments of a civil society in the 'disobedient zone' and that the Sajūdis could not have appeared in an empty place and to have mobilised so fast without social networks, which had been formed in advance. A. Ramonaite thinks that people's efforts to create for themselves a relatively bearable autonomy in the Soviet system and their ability to act independently, to organise themselves on the basis of this autonomy rather than in the ideological scheme imposed on them by the state "from above' 12 contributed to the emergence of a civil society in Lithuania. S. Šiliauskas speaks about opposition to the regime in practical spheres of life and creative work, in a private space. In the opinion of this scholar 'micro-civil' manifestations of the state can be seen due to the fact that Soviet institutional homogeneity failed to choke the individuals' self-image altogether. ${ }^{13}$ Therefore, the perceived withdrawal from the communist principles, though it was not always a public and systematic action, could create the principles of the 'silent society' that was indifferent to the regime. In addition, the scheme of functioning of private-informal-public-power spheres in Soviet Lithuania formed by the historian V. Klumbys is worth mentioning. ${ }^{14}$ On the basis of Klumbys' observations one can understand more clearly that as far back as the nineteenth century a strong informal (unofficial) space in which the part of society disobedient to the tsarist authorities and later the government under President Smetona of Lithuania, or to the Soviet authorities acted and at the same time created or influenced the public opinion. Since in Soviet times the public (official) space was controlled by the regime, in his opinion, it

${ }^{12}$ Ramonaitè, 'Pilietinè visuomenè'.

${ }^{13} \mathrm{~S}$. Šiliauskas, 'Pilietinès visuomenès ižzalga Lietuvoje', Pilietiné visuomené: politikos ipilietinimo projekcija, ed. S. Šilauskas (Vilnius, 2006), pp. 132-133.

${ }^{14} \mathrm{~V}$. Klumbys, 'Lietuvos kultūrinio elito elgsenos modeliai Sovietmečiu'. Unpublished doctoral dissertation, University of Vilnius, 2009. 
was the intellectuals who could express values of an alternative discourse in official publicity transferring them from an unofficial public space. ${ }^{15}$

Having put together the considerations of foreign authors about a civil community, citizenship and observations of Lithuanian researchers about the possibilities of such a civil action in Soviet Lithuania, the following scheme can be drawn up:

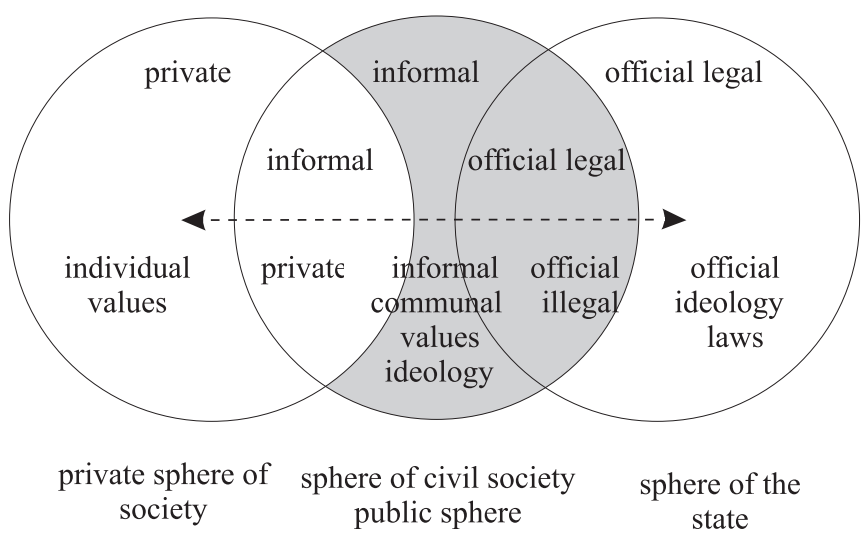

Chart No 1. Sphere of civil society in relation to the private and state sectors.

Three spaces are marked in the diagram: the private space of society, the space of civil society and that of the state in which three spheres form respectively: private-informal-official legal, and certain values articulated by ideology are fostered. These spheres are represented as overlapping since the same or different individuals acting within them seek for different purposes basing themselves on the norms and values existing in different spheres. Therefore, the most interesting activities within the context under research would be those activities, which encompass different spheres: private and informal and official (il)legal in the informal medium. Since informal organisations or informal action overstepped the borders of private entertainment in the Soviet times, publicity was created not only in an official media but also in an informal one (public space is made more

${ }^{15}$ Idem, 'Visuomenès nuomonès veikimo sąlygos Sovietinėje Lietuvoje', Lietuvos istorijos studijos, 19 (2007), pp. 124-137. 
distinct). ${ }^{16}$ The middle arrow shows the possibility of the interaction of values and ideologies from the private medium to the official one and visa versa. For example, if we have in mind the informal action of the intellectuals during the Soviet period, the latter could have an impact not only on the official Soviet environment but also to Sovietise an informal or private sphere. In other words, here the problem can be raised whether the only official Soviet system manipulated the society and the groups acting therein or there were cases when members of the society, intellectuals in making use of their symbolic capital managed manipulate the system seeking to achieve alternative aims. One can think that such manifestations of non-systematic citizenship could also determine legitimisation of the Soviet power. On the other hand, repeated actions of informal small groups thereby it was sought to achieve non-systematic aims, that is, aims that were not directly related to the Soviet system, could have been a rehearsal and could form a peculiar habitus, which later served Lithuanian society in regaining true freedom of public action, winning independence and the democratic system in the country.

When raising the question within the context of this research about whether there was a civil society in Lithuania, the answer would be negative. This is so because the public space was controlled at the maximum (the private space was sought to be controlled through it too) and repressions to more tangible anti- and non-systematic manifestations were applied or at least they were sought to be successfully neutralise. All horizontal relationships publicly seen were actually broken in society during the Soviet period. In addition, if public associations, societies and any other public circles operated, their functioning was dictated 'from above'. At the same time, however, there existed separate anti-, non-systematic groups, which operated in the informal and unofficial environment and their functioning had many features of citizenship: solidarity, engagement, seeking for common good, trust. In the same way, in some cases and during different period informal groups, most often those of intellectuals and formed in the surrounding of the intellectuals, covered themselves with the officially existing organisations that were sanctioned by the authorities

${ }^{16} \mathrm{~J}$. Habermas derives the public sphere from the private sector, which would correspond with the informal sphere in the above-presented scheme, which overlaps with the private one. See: J. Habermas, The Structural Transformation of the Bourgeois Public Sphere: An Inquiry into a Category of Bourgeois Society (Cambridge, 1996), p. 30. 
(the Ramuva movement, Strazdelis University, Sigma, Žinija discussion clubs, societies of philosophers, artists and informal circles and so on). It was only because Lithuanian society was atomised that in many cases such break-through of nationality and citizenship could not reach broad masses as it was in Poland, Czechoslovakia and Hungary where scopes of totalitarian control were more moderate as compared with those in the Soviet Union. One can guess that a peculiar network of informal organisations existed in Soviet Lithuania, which most probably formed a parallel society. However, this would form the subject of another research and another article. ${ }^{17}$

Nonetheless, the essential difference in comparing manifestations of citizenship in Western society and Soviet Lithuania is the criterion of political and social freedom. It is true, for a Western civil society to appear free elections and the legal authority elected democratically in this way were necessary. No matter what civil initiatives could come 'from below', in normal conditions, they should have relation not with the authority established by the military power of a foreign state but with the politicians elected. In addition, in normal democratic conditions there could be no restrictions of the security police and repressive measures applied to an independent communal and public action. Hence, looking at it from this point of view, it would seem that in a totalitarian state real citizenship could have manifested itself only through public rejection or criticism of such authority and powers it employed, which was characteristic of an anti-systematic action in underground or dissident groups. Having in mind this aspect one can speak about other forms of citizenship only conditionally.

Alternatives to citizenship in Lithuania The official Soviet authorities could tolerate only single Soviet citizenship, which manifested itself through the creation of the 'new man', the 'new tomorrow' and the 'new society'. When asking what it meant to be Soviet, and who controlled Soviet identity, first, two aspects can be singled out: loyalty to the Communist Party, the mechanism of its governing and belief in the official ideology. ${ }^{18}$ One could speak here, depending on the period and the social group, about the manifestations of transformation of this identity and distorted practices of Sovietism: hypocrisy and

${ }^{17}$ Currently such research is being carried out, see: Ramonaitè, 'Pilietinè', p. 252.

${ }^{18}$ A. Walicki, Marksizmas ir šuolis i laisvès karalystę (Vilnius, 2005), pp. 536551. Also Z. Norkus, Kokia demokratija, koks kapitalizmas? Pokomunistine transformacija Lietuvoje lyginamosios istorinès sociologijos požiūriu (Vilnius, 2008), p. 224. 
conformism of different level and kind - what many people who lived in the conditions of the totalitarian regime found it difficult to avoid. It would be naïve to expect to find real principles of functioning of the Soviet society, the state and its identity in the constitution, which existed in official documents only. The laws enshrined therein comply in part with the principles and human rights of other democratic systems. It was clear to any citizen who was born in a Soviet state that different human rights and rights of a citizen - rights of assembly, of free speech, of conscience, of demonstrations, of demonstration, convictions, elections etc. - did not exist. ${ }^{19}$ Therefore, real Soviet citizenship was constructed purely on the basis of formal citizenship: all people who resided in the Soviet Union had to take Soviet citizenship because they lived and acted in the territory of that state. However, only a part ${ }^{20}$ of these citizens was loyal to the party and the system of the government created by it or had an absolute belief in the idea of communism and acted according to it in a public space, for example, young communist activists, a part of ideologically engaged members of pioneer, education organisations who, on their initiative and by their self-discipline, followed the state's directives thus rendering work of official institutions more efficient. It was their activity that the Soviet authorities tolerated, 'basing itself' on the constitution. This can be referred to as real Soviet or systematic social awareness. Meanwhile dissidents, people who acted in the underground, though appealing to the Soviet constitution and human rights quite often publicly and at an informal level, demonstrated hostility to the Soviet regime, which, in its turn, did not recognise disloyal people. Therefore, the activities of the dissidents and members of underground organisations can be referred to as anti-Soviet or anti-system. Here come the intellectuals and individuals or their groups who are critically disposed towards the system on the whole and who express this by their actions at different levels. They were neither loyal to the system nor believed in the idea of communism though they tolerated adjustment of one or another level because they themselves both worked and acted in an

${ }^{19}$ B. Stasiukaitis, 'TSRS - demokratiškiausia šalis pasaulyje, arba tos šalies konstitucija jos piliečio požiūriu', Perspektyvos. Lietuvos pogrindžio periodinis leidinys, 1978-1981, ed. P. Vaitkūnas (Vilnius, 2005), pp. 783-808.

${ }^{20}$ Special studies are necessary to determine this part. For example, there were such researchers as A. Stromas who stated in 1977 that in a sense all residents of the Soviet state were political prisoners, see: 'Opozicija Tarybu Sajungoje', in A. Štromas, Laisvès horizontai (Vilnius, 2001), p. 36. 
official space. These groups often made use of the mistakes made by the Soviet system, political instability, though they did not criticise the system itself as such. ${ }^{21}$ So the members of these groups could publish articles, books, could organize different activities in public, which did not meet the official line and made the system weaker. Chart Two illustrates these three kinds of social groups and their possible action in the space of a civil society:

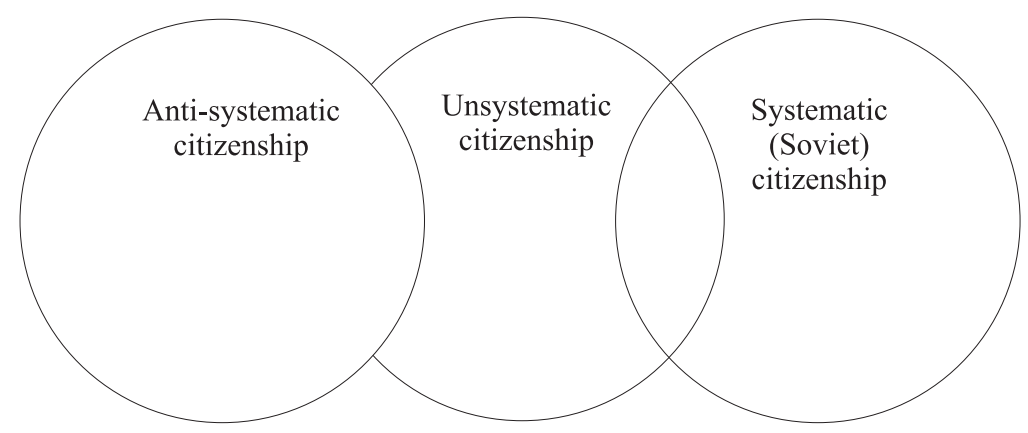

Chart No 2. Alternatives to citizenship in Lithuania

Three alternatives to citizenship represented in the diagram intertwine. This is because sometimes the same actions of individuals of the unsystematic group could be interpreted as useful (with respect to propaganda of the Western countries) and doing no harm to the system but at the same time presenting cultural, scientific alternatives in a society controlled by the Soviets, for example, when organising different events, conferences and campaigns. Alternatively, the same unsystematic actions could also have been interpreted as direct opposition, resistance to the regime. For example, the Ramuva movement, where the hikers were not only interested in ethnography and local history but also they inspired the search for authentic national identity and its formation, and political issues and objectives, which could be started to be realised in the long run were discussed at the informal meetings of this movement too. ${ }^{22}$ In addition, there were people who passed through several forms of engagement in citizenship. In this

${ }^{21}$ Once criticism was expressed, it was done in a refined, hidden, Aesopian language. Most often, these groups were engaged in criticism of separate phenomena of Soviet life, which in part was tolerated by the Soviet system.

${ }^{22}$ One of such examples is the Union of Young Lithuania, see 'Kraštotyrininku byla', Liaudies kultūra, 2007, No. 6, p. 46. 
case, tromas and T. Venclova could be considered to have been loyal to the Soviet authorities in their youth but later they moved to open criticism of the system and established dissident organisations and took part in their activities.

Although all three alternatives can be connected, they convey a very clear difference at the same time. The first one puts efforts to prove the illegitimacy of the Soviet system both on the informal as well as on the official level and seeks to change it using civilized methods. The second position does not really have any intention to change it but with all kinds of actions on different occasions creates such elements, which make the system weaker. The third position of citizenship demonstrates its belief on every level of action that Soviet socialism is the only true political, economic or ideological system for society and it tries to make it more active and effective.

\section{Informal groups of intellectuals and their activity in Soviet}

Lithuania It should be noted that during the late Soviet period in Vilnius, like all over Lithuania, many informal groups of intellectuals were formed in different spaces: in flats, editorial offices of more liberal magazines, cafés, on university premises, in institutions of higher education, institutes, and official Soviet organisations. These groups contained intellectuals of a broad educational background: writers, poets, art critics, artists, actors, artistic directors, composers, musicians, philosophers, historians, physicists, chemists, etc. Although these groups flourished and developed in the 1960s, before the Sajūdis movement started, single groups of intellectuals could be found in the years of Stalin's rule and/or after his death. For example, one group of this kind was rallied round a well-known poet, Professor V. Mykolaitis-Putinas, and operated both at the university and in the professor's flat. ${ }^{23}$ According to the secret service documents, several such non/anti-systematic groups of intellectuals could be found in the former capital city of Kaunas. ${ }^{24}$ Informal groups also operated among the students of Leningrad and Moscow. The latter, together with the Latvian and Estonian students, formed the ensemble Balticum.

${ }^{23}$ M. Lukšienė, 'Vivos plango', Atsiminimai apie Vinca Mykolaiti-Putina, ed. D. Mitaite (Vilnius, 1992), pp. 342-360.

${ }^{24}$ LSSR valstybès saugumo ministro P. Kapralovo pažyma apie lietuvių inteligentijos pasisakymus dèl tautos dvasinio gyvenimo naikinimo, $1950 \mathrm{~m}$. birželio 9 d.' 'Lietuvos kultūra Sovietinès ideologijos nelaisveje, 1940-1990: dokumentu rinkinys [hereafter - LKS], ed. J. R. Bagušauskas, A. Streikus (Vilnius, 2005), p.136. 
Frequenters of informal groups celebrated birthdays, discussed the latest news of science and art, invited opera singers, organised dance and song evenings, but at the same time they never avoided historical and political topics. Participatns in the gatherings of these groups were dissidents, emigrants or people who were strongly biased against the system: V. Petkus, A. Terleckas, Fathers B. Bulika, V. Aliulis and K. Vasiliauskas; A. Greimas, V. Kelertienè, L. Mockūnas and intellectuals of inter-war Lithuania. Some of them were recruited by the state national security. The important thing is that in such an alternative informal environment they could express non-Soviet ideas, disassociate themselves from over-Sovietised science and art, and create an alternative interpretational context for themselves. These gatherings were neither merely accidental parties nor theoretical discussions or 'grumblings in the kitchen' against the authorities. During these meetings actions were planed that sought to change the Soviet reality or cherish manifestations of non-Soviet lifestyle, an alternative collective identity within the framework of the system, were concretely planned. Apart from these actions, which were directed towards official publicity, the intellectuals expressed their solidarity with the movement of the dissidents: they distributed samizdat, handed over material to the underground press, kept up with the dissident trials, co-operated with the intellectuals-emigrants etc. Most probably the most important feature of these informal groups was that they acted in an official environment since each of their members had a certain social status, could make use of at least a partly privileged position of a scientist in society, could make use of his/her symbolic capital and relations with the nomenclature when seeking to achieve some or other alternative goals. Having adapted themselves to acting in official publicity, the intellectuals were well acquainted with the environment of the nomenclature, personal qualities of the party leaders, their social environments, aims, Soviet unwritten rules, such as what is sauce for the goose, is not sauce for the gander. All this helped greatly in seeking to overcome principles of come fanatically disposed ideologists in Lithuania. Not to make these considerations seem speculative, it is necessary to analyse expressions of such an unsystematic action, which under normal conditions of a democratic society could be called simply the functioning of civil society, in more depth.

Preserving the cultural heritage in Vilnius In Soviet Lithuania, an alternative public opinion existed alongside the official policy, and it often manifested itself through the activity of different above-de- 
scribed groups. ${ }^{25}$ Since the end of the Second World War cultural heritage has been a topical issue in Lithuania (perhaps even more topical than during the interwar period) because of both its material authenticity and its subjectivisation or values attached to it. It is not surprising that the informal groups of intellectuals also considered these issues actively and looked for certain solutions. The strong point of these groups was not only that its members held certain positions in the official world of science and culture but they also contained specialists who could help form adequate arguments concerning one or another object of heritage and exert influence on decision making. Two small groups can be distinguished in the sphere of cultural heritage (though there could have been more of them, especially later after the Sajūdis had appeared, for example V. Čepaitis' group) who gathered in the flats of the literary and art critic I. Kostkevičiūtè, G. Martinaitienè, an employee of the 'Kultūros barai' magazine, and poet M. Martinaitis. The first group consisted of V. Zaborskaitè, M. Lukšienè, J. Lebedys, D. Sauka, L. Noreika, B. Genzelis, I. Lukšaitè, Z. Žemaitytė, Father Kazimieras Vasiliauskas, and others. ${ }^{26}$ The following individuals participated in the flats of G. and M. Martinaitis: B. Genzelis, I. Kostkevičiūte, I. Lukšaitè, S. Mičelyte, A. and V. Nasvyčiai, V.Landsbergis, S. Geda, D. Katkus, P. Repšys, J. Aputis, J. Vaičiūnaitè, V. Zaborskate, L. Noreika, V. Kernagis, A. Kukaitis, A. Skučas, L. Mockūnas, V. Kelertienė, V. Petkus, V. Čepaitis. ${ }^{27}$ The topics of these groups' conversations or activities were related to different themes of culture. For example, Irena Kostkevičiūte's group formed and discussed mainly Mykolaitis-Putinas' creative work and issues arising from it. ${ }^{28}$ Not all the above-mentioned individuals formed the kernel of the group and attended its meetings regularly or were accepted by other members of the group unconditionally. According to their professions, as well as the spheres of their activities, they were very different personalities. Primary professional or existential interest of the intellectuals was culture, however, the latter differed in that they were not afraid to overstep their professional limits and look

\footnotetext{
${ }^{25}$ More about the functioning of the public opinion in Lithuania see Klumbys, 'Visuomenès nuomonès'.

${ }^{26}$ M. Martinaitis, 'Iki Sajūdžio ir po jo', Sajūdis ateina iš toli, ed. R. Gudaitis, A. Rybelis, A. Rupšyte (Vilnius, 2008), pp. 477-478.

${ }^{27}$ The author's interview with Gražina Martinaitienè on 12 Oct. 2009 (the author's conversations are stored in his personal archive).

${ }^{28}$ Martinaitis, 'Iki Sajūdžio'.
} 
for unindoctrinated forms of culture in the life of the Soviet society. In this way, for example, an entirely new project of sung poetry between Martinaitis, Kukaitis and Kernagis was born. ${ }^{29}$ Noreika and Martinaitis started to organise poetry evenings in which the ideas of a person's creative freedom and patriotism were expressed in different places in Lithuania. ${ }^{30}$ In investigating unsystematic manifestation of citizenship, however, attention is drawn to the efforts of the end of the 1970s and later years to put a stop to the attempts of the functionaries of the city of Vilnius to reconstruct the Old Town destroying more or less valuable objects of the cultural heritage. In 1977, Kostkevičiūte and Martinaitiene undertook the initiative to collect signatures seeking to preserve the gothic basements of the renaissance epoch uncovered in Stikliu Street. Drawn into this campaign was not only a part of the participants in said groups but also residents of the quarter, persons belonging to other informal groups of intellectuals. This civic activity - collection of signatures, a public protest in discussions with responsible functionaries - was not illegal with respect to the regime because Soviet bureaucracy, ideologists were not quite decided on the interpretation and take-over of non-Soviet heritage. ${ }^{31}$ The theory of 'two cultures' and a selective attitude to the objects of the past existed. However, the legacy of the 'ruling class', 'bourgeoisie' was not treated equally with proletariat culture. ${ }^{32}$ Monuments of the past, churches, and manor houses were restored in single cases only, and mainly as objects of tourism to be shown to foreign guests or, as in case of Trakai Castle, as examples of anti-Western action in local culture. At the same time, the Soviet authorities could strengthen the status of its legality in the eyes of the public. Even the branch of ICOMOS, which was regarded as one of the examples of heritage conservation in the Soviet Union, established in Lithuania, failed to ensure (or perhaps deliberately tried not to do ensure) protection from economic decisions taken by technocrats that were destructive to her-

${ }^{29}$ The author's interview with Gražina Martinaitienè on 12 Oct. 2009. Also R. Oginskaitè, Nes nežinojau, kad tu nežinai. Knyga apie Vytauta Kernagi (Vilnius, 2010), pp. 275-286.

${ }^{30}$ L. Noreika, Aktoriaus dienoraščiai (Vilnius, 1999).

31 'LKP CK biuro nutarimas dẻl kultūros paminklų apsaugos pagerinimo ir jų panaudojimo propagandos tikslams, $1958 \mathrm{~m}$. gegužès 12 d.' and 'LKP CK biuro nutarimas dèl politinių klaidų vykdant architektūros paminklų apsaugą, $1961 \mathrm{~m}$. birželio 9 d.', $L K S$, Nos 63, 74, pp. 259-263, 287-289.

${ }^{32} \mathrm{R}$. Čepaitienè, Laikas ir akmenys. Kultūros paveldo sampratos moderniojoje Lietuvoje (Vilnius, 2005), pp. 149-154. 
itage. Martinaitis wrote about this type of bureaucratic decision in his dairy in 1977: "The rise of the so-called "standard of living", the strengthening of certain material strata become a destructive power. It is symbolic that they attack culture, its historical values, for instance Vilnius' Old Town. Materialistic power strives to legitimate itself when the materialistic benefits law is enacted. It starts putting everything into the shadow, even the most important cultural values. Even wars or natural disasters cannot destroy it so as a materialized man, who is no more in danger of hunger or death' ${ }^{33}$ The decision of the Executive Committee of the city of Vilnius made at the end of the 1970s to build garages in Stikliu Street that would damage the heritage of the Old Town without carrying out archaeological excavations or attempts to build a highway through the Old Town were examples of negligence, unfounded pragmatism of the Soviet bureaucracy and, at the same time, perhaps examples of ideologised thinking ${ }^{34}$, similar to turning churches into warehouses and museums of atheism. In such cases, the authorities allowed society to interfere.$^{35}$ It is interesting to note that in case of said garages in Vilnius, like in other similar cases, networks of informal groups worked, which, supporting one another, making use of their acquired social status, using Soviet phrases understandable to the system and connections with the high-ranking officials of the Soviet republic achieved their goal. G. Martinaitiene spoke about that: 'I remember that then we thought that it was necessary to collect signatures of the people residing in the Old Town and the centre. Then Marcelijus [Martinaitis] sat and wrote an official letter to the Supreme Soviet, saying that it was impossible to do that (a copy of that official letter is available). One of the restorers and I

${ }^{33}$ M. Martinaitis, Tylintys tekstai (užrašai iš raudonojo sqsiuvinio): 1971-2001 (Vilnius, 2006), p. 91.

${ }^{34}$ J. Maniušis andr M. Kenevičius in their report to A. Sniečkus treated the opposition of architects to the destruction of the historical architectural heritage of Lithuania as idealisation of the past and as a political mistake, see: 'J. Maniušio ir M. Kenevičiaus pranešimas LKP CK pirmajam sekretoriui A. Sniečkui apie LSSR architektų sajungos antrojo suvažiaviumo delegatų priešinimąsi Lietuvos istorinio architektūros palikimo naikinimui ir politinès kontrolès stiprinimą“, 1955 lapkričio 14 d.', $L K S$, pp. 219-225.

${ }^{35}$ Such protests of intellectuals took place in Moscow in 1973 when the Town Hall, the Museum of History, Stanislavski Theatre and other buildings of the tsarist period were saved. There were similar initiatives of the heritage conservation among the Russian intellectuals in the 1960s too. See: H. Smith, The Russians (New York, 1995), p. 576. 
went through the flats with that letter. These letters contain stains of fat. We entered one flat and a woman was frying pancakes. We say, 'Look, they are destroying this place, will you sign?' She signed. At another place, a KGB man working opened the door, and at another place we were turned out. However, many signatures were collected. Then the question arose how to hand the letter to the session, because the letter was written to Griškevičius. Marcelijus calls Mieželaitis. ... When the session begins, Marcelijus and I take that paper with oil stains to the Philharmonic Society. Mieželaitis comes running out of the building, we hand him the letter and Mieželaitis puts the letter into Griškevičius' hand in the presidium. The participants who were there said, "Glemža, who sat there turned livid!" Then the issue was considered and Griškevičius said: "That's settled. There should be no garages there!" (The Bureau of the Central Committee seemed to have approved that). Later the pits dug for would-be garages filled with water. ${ }^{36}$

If such letters of indignation and petitions had been mailed, they would have never achieved their purpose. Had it been done more often (which was done later) that would have aroused suspicion of the highest institutions and the state security. Therefore, connections were used seeking to achieve a general purpose useful to the nation and society. The above presented quotation shows the whole process from the lowest level to the leader of the Lithuanian Soviet Socialist Republic. At that time, it was known that taking such measures it was possible to make Griškevičius change his mind if there were no instructions from Moscow. ${ }^{37}$ In addition to this, the intellectuals succeeded in having an official discussion with the Executive Committee members of Vilnius and with the functionaries responsible for its cultural heritage..$^{38}$ The historian Vytautas Merkys, who was also engaged in the problems of heritage conservation, states that taking similar measures attempts were made to preserve other objects or their harmonious architectural environment. ${ }^{39}$ It is important to add that another way to influence the cultural heritage policy in the $1960 \mathrm{~s}$, 1970s and 1980s was the Soviet Lithuanian press: 'Kultūros barai',

${ }^{36}$ The author's interview with Gražina Martinaitienè, 12 Sept. 2009.

${ }^{37}$ The author's interview with Bronius Genzelis, 25 Nov. 2010.

${ }^{38} \mathrm{~V}$. Merkys, 'Ar statys garažus po Vilniaus katedra? (Vilniaus senamiesčio apsaugos problemos sovietiniais laikais)', Lietuvos istorijos metraštis, 1998, pp. 265-278.

${ }^{39} \mathrm{~V}$. Merkys, Atminties prošvaistès. Atsiminimai (Vilnius, 2009), pp. 242-245. 
'Mokslas ir gyvenimas', 'Muziejai ir paminklai', 'Literatūra ir menas' etc. Besides specialists, representatives of different social strata took part in these discussions. ${ }^{40}$

In summing up the question why such activity by intellectuals and other ordinary 'Soviet' citizens is to be treated as an example of unsystematic activity and citizenship rather than as an example of the Soviet activity, the following arguments can be presented: 1) though the highest Soviet authorities allowed society to show initiative, ideologically unacceptable cultural heritage was not an object of attention, unless it served the purposes of propaganda with respect to foreign countries, immigration or as a means of legitimisation of power permeated with national sentiments; 2) during the late Soviet period attempts to protect objects of culture were made quite often and in different towns of Lithuania (for example, in Kedainiai seeking to preserve the graves of the Radvila [Radziwiłł] family and others in the town's Calvinist $\mathrm{Church}^{41}$ ); 3) preserving authenticity reminded the society of the Soviet period that prior to the Soviet system a different social, cultural and political past of Lithuania existed; the environment of culture in Vilnius and all over Lithuania exited feelings of self-respect and pride, strengthened national identity (for example, Gothic architecture did not reach Russia at all) ${ }^{42}$; 4) not only architects but also a large part of intellectuals of other specialities and wider strata of society took part in the heritage conservation movement. Those intellectuals who were related to informal activities of protecting the cultural heritage, risked to be downgraded or subject to other measures because of criticism of the town authorities, and solidarity that they demonstrated, action of the social networks could attract attention of the security structures, 5) it is in this civil activity that the collective identity of non-systematic intellectuals who did not have enough courage or motivation to move to the forms of dissident activities but who did not identify themselves with the loyal or indoctrinated activists of the Soviet elite, formed. The latter case is also interesting in that the informal groups of the intellectuals used

\footnotetext{
${ }^{40}$ For further study see Čepaitienè, Laikas, pp. 232-248. This periodical cultural press discussion is also interesting. But since the object of this article is citizenship, i.e. certain ideas and their realization actions and ways, we examine only some practical examples.

${ }^{41}$ The author's interview with Ingè Lukšaite, 19 Apr. 2008.

${ }^{42} \mathrm{~S}$. Kulevičius, Lietuvos paveldosaugos idejjiniai modeliai ir jų raiška praktikoje. Unpublished doctoral dissertation, University of Vilnius, 2010.
} 
to form around the axis of the collective identity 'us' - 'them'. ${ }^{43}$ Victory in the sphere of the cultural heritage or ethnic festivals organised by Ramuva allowed members of 'our' groups to separate themselves from 'them' who were becoming more and more like or tried to create the so-called 'new man'. ${ }^{44}$

\section{The Friends of Lithuania and India Society, Ramuva and the} hikers Another wave of citizenship and public activity among intellectuals in legal space started in the 1960s. This can be related to the events in Czechoslovakia, and in the cultural intellectual world to a decrease in censorship. In 1967, a Friends of India Society was established at Vilnius University as a subdivision of the official organisation the Society for Cultural Relations with Foreign Countries, which sought to take interest in culture, religion and philosophy of that country. V. Bagdonavičius, J. Trinkūnas, A. Gudelis, A. Andriuškevičius, A. Danielius ${ }^{45}$ were among the main organisers. First, this activity manifested itself among the philologists who took interest in the Sanskrit, its relation with the Lithuanian language. Professors V. Mažiulis, Z. Zinkevičius and R. Mironas ${ }^{46}$ gave lectures there. In the end, proposals were made to go deeper into Baltic culture, and interest in Indian culture flagged. ${ }^{47}$ It is worth mentioning that the members of society became engaged not only in the academic activities, and contributed articles about it to the press but also began to organise mass events in Lithuania: in 1967, the Midsummer [Rasos, St John the Baptist's Day] holiday, in 1968, a meeting in commemoration of Vydūnas who was also related to research into Indian culture, in 1969, a meeting in which advantages of the activity of Mahatma Ghandi as compared to those of Vydūnas were highlighted. Perhaps the greatest advantage of the Friends of India Society was that it created an official precedence to take interest in Lithuanian ethnic culture, to organise folklore studies and ethnographic expeditions. Popular ethnographer N. Vèlius, other scholars of Vilnius University

${ }^{43}$ More about manifestations of alternative collective identity see A. Sukys, 'Intelektualų neformalių grupių veikimo bruožai ir opozicinès nuostatos Sovietinèje Lietuvoje', Darbai ir dienos, 54 (2011), pp. 9-35

${ }^{44} \mathrm{~V}$. Čiubrinskas. 'Identity and the Revival of Tradition in Lithuania: An Insider's View', Folk, 42 (2000), pp. 19-40.

${ }^{45}$ S. Matulevičienè, 'Iš Rasos šventès istorijos', Liaudies kultūra, 2007, No. 3, pp. 64-69.

${ }^{46}$ The author's interview with Vacys Bagdonavičius, 6 Dec. 2008.

${ }^{47}$ Ibid. 
engaged members of Ramuva and the hikers in complex research in different places of Lithuania. ${ }^{48}$ The fact that the events organised by the members of Ramuva attracted hundreds of interested young people and finally attention of the state security services, showed that the official limits of permissibility were greatly overstepped and this gave reasons to believe that an organisation was forming in a legal space, which was not subordinate to the control measures of the authorities. Thus, it was possible to see the 'political' aspect too. ${ }^{49}$ In this case, however, political awareness sooner corresponds to social awareness in the sense it is presented in this article: an informal initiative, which unites people into a group and in the course of the public activity of which organisational, ideological aspects alternative or even hostile to the official cultural policy in Soviet Lithuania crystallise even more. The fact that people who practised Catholic values ${ }^{50}$ also found common language with those who cherished the (pseudo)pagan tradition $^{51}$ in Ramuva testifies to the common ambition of the movement (the common good).

The hikers who were engaged not so much in sport tourism as in getting to know the country, and the formation of national-cultural identity also ignored the limits of legality/illegality: 'The aim of the hikers in Lithuania was different - to discover, to get to know, to preserve Lithuanian cultural memory that was withdrawing from life; to learn from communication with people'. ${ }^{52}$ They were engaged also in heritage conservation and heritage protection: 'During the marches ethnographical evenings, collective help in heritage protection were often organised, facts of violating protection of natural and cultural monuments were recorded. Special booklets containing descriptions of places of interest, song texts were 'published'. ${ }^{53}$ T. Šidiškis, one of

${ }^{48}$ Norbertas Vèlius, ed. I. Seliukaitè, P. Vitkuvienè (Vilnius, 1999); V. Mačiekus, 'Vilniaus universiteto kraštotyrininkų ramuvos kompleksinès ekspedicijos: folkloro rinkimo ir tautiškumo ugdymo patirtys', Tautosakos darbai, 37 (2009), pp. 198-212.

${ }^{49}$ A. Šliogeris, 'Sąmonès laisvejjimo ištakų beeiškant', Akiračiai, 1993, No. 2, p. 9.

50 'Paulius Subačius kalbina Algirdą Patacką. Apie „Ramuvą“, tėvyniškumą ir neperžengiamas ribas', Naujasis Židinys, 1994, No. 1, pp. 43-50. However, according to Patackas, the Catholic wing refrained from participating in official culture with certain exceptions. See ibid. p. 46.

${ }^{51}$ J. Trinkūnas, Nuo Ramuvos iki Romuvos, in: <http:/gyvenimas.delfi.lt/stories/ jtrinkunas-nuo-ramuvos-iki-romuvos.d? id=33802309>, [address visited on 7 Oct. 2011].

52 'Kraštotyrininkų byla', Liaudies kultūra, 2007, No. 6, p. 49.

${ }^{53} \mathrm{~V}$. Almonaitis, 'Vilniaus universiteto istorijos fakulteto žygeivių bendrijos „Aitvaras“ istorijos bruožai', Atbalsis, 1996. 
the main organisers of the hikers, says that when visiting Lithuanian communities in the territory of Belarus they subscribed the press for them, organised social evenings, helped the children of the Lithuanians living there to be admitted to schools in Lithuania. ${ }^{54}$ Also, at the request of academician Tadas Ivanauskas a map of Lithuanian 'islands' was drawn, which later he handed to A. Sniečkus with a request to establish Lithuanian schools in Belarus. In 1969, a campaign was launched seeking to preserve Darius' homestead putting it on the list of protected monuments. In the same year, the monument to Lithuanian's independence in Vi tytis was renewed; in 1970, a monument to the volunteers of independent Lithuania was discovered in Latvia. These and other campaigns received the same reaction from the authorities - in 1971, the hikers' club of Vilnius University was banned. However, this did not put a stop to the hikers' movement, which survived until the Sajūdis years.

Conclusions The model of community-based citizenship, which forms the media for social action between the official, private and state spheres of society, can be applied to conditionally explain civic activities of the Soviet Lithuanian society because citizens in Soviet Lithuania were deprived of the most important conditions such as free democratic elections, public influence on their elected representatives; their opportunities for action were limited by state security structures. Anti-systematic activity, that is, uncompromising open resistance, and criticism of the Soviet authorities on all the issues of human and citizen's rights was closer to the western conception of citizenship.

Three manifestations of citizenship can be found in the sphere of activity of a civil society during the Soviet years: anti-systematic, non-systematic and systematic. Many elements characteristic of the Western civic activity model are observed in the non-systematic activity analysed in the present article: independent action, organisation 'from below', seeking a common goal, solidarity, trust, aspiration to defend some human and citizen's rights in public. Many manifestations of this non-systematic action are characteristic of the informal groups of intellectuals whose members had amassed symbolic capital, were well acquainted with the trajectories of functioning of the

${ }^{54}$ These and other facts of the hikers'activities are presented on the basis of testimonies of the main organiser Tadas Šidiškis, see T. Šidiškis, 'Keturiasdešimt metu su žygeiviais', Liaudies kultūra, 2008, No. 3, pp. 58-62. 
Soviet power in Lithuania and through their action could influence the solution of some cultural and social problems.

The most distinct actions of civic activities in a legal or semi-legal space seeking to achieve non-systematic aims manifested themselves in the spheres of heritage conservation and the ethnographic and folklore movement. In the case of heritage conservation, this was a legal activity because the Soviet authorities in Lithuania were not fully determined as to what kind of heritage should be protected. The local history movement encouraged not only searches for an alternative, authentic Lithuanian identity but also actions, which sought to defend the interests of Lithuanian culture with respect to the policy permeated by Soviet internationalism. Petitions, public discussions, campaigns, concerts, conferences, commemorations of the events and personalities of Lithuanian cultural life, which were initiated by the kernel groups formed of intellectuals, were manifestations of this conditional non-systematic Soviet awareness in Soviet Lithuania. They show that during the late Soviet period the totalitarian system itself, mitigating the repressive clutches, created conditions for alternative forms of action to appear in Lithuania.

\title{
Author Details
}

Aurimas Šukys is a doctoral student at the Department of Lithuanian History at Vytautas Magnus University (from 2007). His object of research: informal groups of intellectuals in Soviet Lithuania and their opposition activity in the legal, semilegal environment. Vytautas Magnus University, Faculty of Humanities, Department of History.

Address: K. Donelaičio g. 52, LT-44244 Kaunas

Email: aurimas_sukys@yahoo.com

\section{PILIETIŠKUMAS IR SOVIETŲ LIETUVOS INTELEKTUALŲ NESISTEMINE VEIKLA}

\author{
Santrauka
}

\section{AURIMAS ŠUKYS}

Straipsnio objektas yra intelektulų nesisteminis veikimas Sovietų Lietuvoje vertinant ji pilietiškumo kriterijumi. Nesisteminis veikimas suprantamas kaip marksizmo-leninizmo ideologijos ir ją vienokia ar kitokia forma įūnijančios sovietinès totalitarinès valstybès neatitinkanti kasdieninè, institucinè ar teorinè veikla. Remiamasi prielaida, kad ta totalitarinès valstybès forma, kokią turèjo išgyventi Lietuvos 
visuomenė po Antrojo pasaulinio karo ir ypač po Stalino mirties, ilgainiui vis labiau keitèsi, sudarydama tam tikras palankias galimybes (galbūt pati sistema ne visada tai galèdavo suprasti ir kontroliuoti) savarankiškam visuomeniniam veikimui. Kitas svarbus terminas - „pilietiškumas” - straipsnyje vartojamas ne liberaliaja, bet respublikoniškaja prasme: pabrěžiamas valstybès gyventojų dalyvavimas „,iš apačios” besiformuojančioje visuomeninèje veikloje, kuria siekiama apginti bendraji, viešaji interesą, žmogaus ir piliečio teises. Straipsnyje, remiantis teorine ịvairių autorių analize, pateikiamas bendras Vakaru visuomenèje egzistuojantis pilietinès visuomenès funkcionavimo modelis ir jo pagrindu konstatuojama, kad Sovietų Lietuvoje būta trijų tokio pilietiškumo apraiškų: antsisteminio (būdingo partizanams, disidentų grupèms), nesisteminio (būdingo intelektualų neformalioms grupèms, kurios veikè legalioje arba pusiau legalioje erdveje) ir sisteminio (vadinamojo tikrojo tarybiškumo, kuris buvo būdingas komunistinių organizacijų aktyvistams ar daliai visuomenès, pripažinusios komunistinę ideologiją). Pagrindinè problema, kuri iškyla taikant pilietiškumo sąvoką sovietinès valstybès visuomenei, yra tokia: ar apskritai galima kalbèti apie pilietinę visuomenę totalitarinio režimo sąlygomis. Straipsnio autorius i šị klausimą atsako neigiamai, tačiau kartu pateikia organizuoto veikimo pavyzdžių iš ¿̇vairių Lietuvos visuomenès, mokslo, kultūros sričių. Šią veiklą kaip alternatyvų arba nesistemini pilietiškumą daugiausia inicijavo intelektualai. Tai buvo aštuntajame dešimtmetyje prasidejusi paminklosauginè veikla, septintojo dešimtmečio pabaigoje isisiūbavęs etnografinis, kraštotyrinis sajūdis, kurio vedliai taip pat buvo Lietuvos kultūrinio elito atstovai. Straipsnyje pažymima ir tai, kad tokių alternatyvių sajūdžių, judejjimų pagrindas buvo mažesnès bendraminčiu grupelès, kurios susiburdavo privačioje, neformalioje aplinkoje, o jų nariai vadovaudavosi visiškai kitokiomis, negu oficialiai buvo brukamos sovietinès ideologijos, vertybėmis - krikščioniškomis, humanistinèmis, demokratinėmis, tautinèmis, pilietinėmis ir pan. 